\title{
Population aging and inhabitant consciousness of community development: a case study of the rural area in Thua Thien Hue Province, Vietnam
}

\author{
Bui Thi Thu*, Tsutsui Kazunobu, Do Viet Huong
}

\begin{abstract}
Population aging, which is a global phenomenon, has strongly impacted the social lives of many societies around the world. In which, Japan and Vietnam are two of the twenty countries with the largest older population in the world. The "Kaso"- depopulation, has been occurring in rural Japan since the 1960s and has had negative impacts on community development. Vietnam in general, and Thua Thien Hue Province in particular is revealed to be in the beginning period of the "aging phase" - one of the Kaso signs. This paper attempts to clarify (1) how the extent of "Kaso" in Japan occurs in the study area of Vietnam; and (2) how is the inhabitant consciousness on daily life, socioeconomic development status and the concern of local people on the future development of rural community in context of projected population aging. Based on preliminary typology analysis of the demographic statistics (total population, aging population structure) of Thua Thien Hue at the commune level during the period of 1989-2012, two rural communes with aging population characters were chosen for further analysis through household questionnaires. The research result demonstrated that there has been similar to the initial situation of Kaso in rural Japan. However, the deep analysis result indicated that the presence of rural people's negative consciousness of community development is not strong. Those preliminary results enable to emphasize significant importance on providing implicit information on the negative consciousness of rural people regarding the future of rural Vietnam.
\end{abstract}

Keywords - Population aging, Kaso, community development, rural area, Thua Thien Hue

Received: 10-2017, Accepted: 18-11-2017; Published: 306-2018

Bui Thi Thu*, Do Thi Viet Huong, Hue University College of Sciences, Vietnam

Tsutsui Kazunobu, Tottori University, Japan

Email: lapthuhue@gmail.com

\section{INTRODUCTION}

A ccording to report of United Nation, the Aworld's population is aging: virtually all countries are experiencing growth in the number and proportion of older in their populations. Population aging, which is a global phenomenon, has strongly impacted the social lives of many societies around the world. This phenomenon puts pressure on health systems, increasing the demands for care, services and technologies to prevent and treat diseases and chronic conditions associated with old age. The trends in population ageing is projected to be significant in the less developed regions, especially in Africa and Asia. In which, Japan is one of five countries with the largest number of oldest-old person. Vietnam is ranked as $18^{\text {th }}$ in just twenty countries accounted for three quarters of the world's older population [10].

Following the period of rapid economic growth in urban areas of Japan during the 1960s, Japanese rural areas have been experiencing outflows of younger populations for the labor force of urban industries. Therefore, economic problems occurred as a result; for example, basic industries/branches such as agriculture and forestry declined significantly. In addition, depopulation and population aging resulted in the decline of rural individuals' community development. These problems have collectively been known and described as “Kaso" (過疎 in Japanese). Similar to Japan, Vietnam in general and, in particular, Thua Thien Province in Central Vietnam, has begun to see the process of population aging. The rural areas have faced a significantly higher level of population aging compared to the urban areas. 
Under the threat of globalization, communities are facing new and more powerful challeges to their survival, expecially the rural community. Therefore, recently the interest in communitybased development has grown rapidly for offering collective solutions to these problems by building on the existing resources within the community [4].

The question of this research is attempted to clarify (1) how the extent of "Kaso" in Japan occurs in the study area of Vietnam? And (2) how is the inhabitant consciousness on daily life, socio-economic development status and the concern of local people on the future development of rural community in context of projected population aging. This paper approached the term of population aging and "KASO" phenomenon in Japan integrated with questionnaire survey for analyzing the population aging and inhabitant consciousness for community development in rural of Thua Thien Hue Province. The findings of this study will serve a good reference and scientific foundation for local authorities for rural community development in the future.

\section{POPULATION AGING AND "KASO" PHENOMENON IN RURAL AREA OF JAPAN}

\subsection{Population aging}

Population aging is defined as a phenomenon of increasing share of older persons in the population. Recently, it has emerged as one of the most significant social transformations of the twenty-first century, with implications for nearly all sectors of society, including labor and financial markets, the demand for goods and services, such as housing, transportation and social protection, as well as family structures and intergenerational ties [10]. Population aging creates various pressures on economic growth, as well as on the infrastructure and social protection services. In addition, it has significant effects on family relationships and lifestyles [9]. The demand for healthcare and social welfare has increased, and more and more young people migrate to urban areas. At the same time, population aging will have significantly negative effects on the community development, as well as on the maintenance and conservation of the local culture. Thus population aging issues are essential in consideration of national development progress and was highlighted in the goals achievement of the 2030 Agenda for Sustainable Development [10].

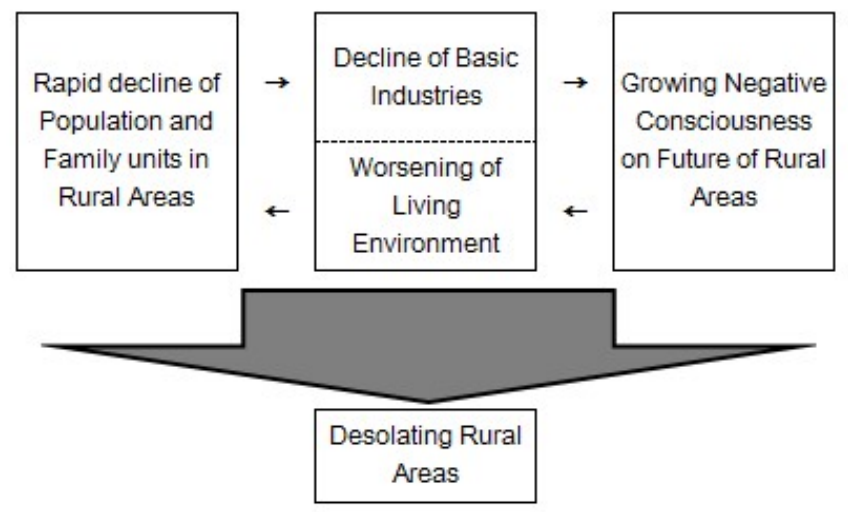

Figure 1. "Process of negative spiral on Kaso", adopted by ADACHI, 1970

\subsection{Kaso in Japan}

In Japan, phenomenon of depopulation progressed significantly during high economic growth in the 1960s. The word depopulation -

“Kaso" (過疎) in Japanese appeared first in a government document in 1966 [6]. The problems include not only depopulation, aging, decline of basic industries, and worsened living environments, but also negative consciousness of rural areas. ADACHI Ikutsune (1970) presented the "Process of negative spiral on Kaso" (Fig. 1), which first involved a rapid decline of population and family units. In the second phase of this process, these declines resulted in the decline of basic industries and the worsening of living 
environment of rural areas. From the deteriorating social environment, economic conditions, and state of community, rural people started to voice a negative perspective toward the future of their areas. This negative consciousness led to the further dwindling of the population and family units. This "process of spiral on Kaso" is eventually oriented in the direction of desolating rural areas. Therefore, from the 1970s, the Japanese Government started to strengthen regional Kaso measures for industrial development and living improvement of rural areas under Kaso-related laws, as follows: the Act on Emergency Measures for Depopulated Areas from 1970 to 1980, the Act of Special Measures for Promoting Depopulated Areas from 1980 to 1990 , the Act on Special Measures for Activation of Depopulated Areas from 1990 to 2000, and the Act on Special Measures for Promotion for Independence for Underpopulated Areas from 2000 to present [1].

\section{METHODOLOGY}

\subsection{Data collection}

The secondary data was collected through sources including reports, the statistical yearbook, and research works from the Thua Thien Hue Department of Statistics, People's Committee of 104 rural communes.

The primary data was collected through two methods, as follows:

- Semi-structured questionnaire interviews with key informants: The authors interviewed two leaders of two People's Committees (that of the Quang Phuoc and Huong Loc communes) for general information, as well as some villages with aging populations and many out-migrant labors.

- Surveying households with structured questionnaires: The implemented questionnaire surveys in the target communes were based on the results of typology of population aging communes.

In this method, the authors applied the simple sampling selection method of Taro Yamane (1967) [11]:
Of which:

$$
n=\frac{N}{1+N E^{2}}
$$

- n: Sample size

- N: Total households

- E: Margin of error desired $( \pm 10 \%)$

The household interviews were conducted in February of 2015. Questionnaires were carried out by the authors with the assistance of village staffs.

\subsection{Data analysis}

3.2.1Typology analysis of the demographic statistics

Socio-economic typology is considered one of the effective methods of grouping diverse geographic objects into entity groups or certain classes with similar characteristics and certain indicators for socio-economic territory organization [7]. In this study, this technique was used to categorize the similar communes in terms of aging problems as well as to analyze their demographic statistics, thereby providing the background for examining the inhabitant consciousness on community development [5].

Based on the total population, the population structure by age group of the rural area in Thua Thien Hue Province during the period of 1989-2012, the preliminary typology analysis of the demographic statistics was implemented.

3.2.2Rural residents' consciousness on community development analysis

Analysis was based on a structured questionnaire with a multi-choice format, which focused on the parameters of four dimensions defined as: the living conditions of community, the natural and socio-economic characteristics of community, the concerns for present community development, and future community development concerns. Each dimension corresponded to various variables (defined clearly in Table 1). 
Table 1.

Variables of rural residents' consciousness on community development

\begin{tabular}{|l|l|l|}
\hline \multirow{4}{*}{ Categories } & \multicolumn{1}{|c|}{ Key word } & \multicolumn{1}{c|}{ Variables } \\
\hline \multirow{4}{*}{$\begin{array}{l}\text { Living conditions } \\
\text { of community }\end{array}$} & Public health service & Sufficient public health services \\
\cline { 2 - 3 } & Grocery & $\begin{array}{l}\text { Often feel convenience in access to grocery or general } \\
\text { shops }\end{array}$ \\
\cline { 2 - 3 } & Educational environment & Often feel educational environment is good \\
\cline { 2 - 3 } & Entertainment areas & Many entertainment areas \\
\cline { 2 - 3 } $\begin{array}{l}\text { Natural-socio- } \\
\text { economic } \\
\text { characteristics of } \\
\text { community }\end{array}$ & Public transportation & Often feel convenience in access to public transportation \\
\cline { 2 - 3 } & Natural landscape & Community has abundant natural landscapes \\
\cline { 2 - 3 } & Community cohesiveness & High frequency of natural disasters \\
\cline { 2 - 3 } & Employment opportunity & High spirit of solidarity, willingness to help \\
\cline { 2 - 3 } & Local economy change & Pood employment opportunities \\
\cline { 2 - 3 } & Household economy change & Positive trend of household economy change (10 years ago) \\
\hline \multirow{5}{*}{$\begin{array}{l}\text { Present community } \\
\text { development } \\
\text { concerns }\end{array}$} & Community knowledge & Knowledgeable about local community \\
\cline { 2 - 3 } & Daily life & Comfortable daily life \\
\cline { 2 - 3 } & $\begin{array}{l}\text { Willingness to stay in } \\
\text { community }\end{array}$ & Prefer living in local community \\
\cline { 2 - 3 } & Life satisfaction & Satisfied with current life \\
\cline { 2 - 3 } & Migration & Want to live far from family, relatives \\
\cline { 2 - 3 } & Community activities & Importance of community's activities \\
\cline { 2 - 3 } & Community concerns & $\begin{array}{l}\text { Often feel frustrated when bad things about the community are } \\
\text { heard }\end{array}$ \\
\cline { 2 - 3 } & Community participation & Often participate in community activities \\
\cline { 2 - 3 } & Community development & Local community is developing \\
\cline { 2 - 3 } & Community life & Community life would be better \\
\cline { 2 - 3 } $\begin{array}{l}\text { Future community } \\
\text { development } \\
\text { concerns }\end{array}$ & New community activities & Need more new community activities \\
\cline { 2 - 3 } & Out-migrated trend & Descendant would like to out-migrate (to city or urban areas) \\
\hline
\end{tabular}

Analysis of inhabitants' consciousness was implemented using Microsoft Excel. The quantification of rural residents' consciousness on community development in each target commune was based on a subjective ranking of the 4-point Likert scale scores, measuring either positive or negative responses to a statement. For example, for the question "High spirit of solidarity, willing to help?" the multiple choices offered were "Very high - High - Few - No" corresponding to score of 4, 3, 2, and 1, respectively. Conversely, for the question "Descendant would like to out-migrate (to the city, urban)?" the multiple choices offered were "Very desirable - Desirable - Less desirable - Not desirable" corresponding to score of 1, 2, 3, and 4, respectively. An average score was calculated for each dimension, and an overall average of the four dimensions was established, enabling quantitative comparison of rural residents' consciousness on community development. The above result is presented visibly by radar charts for examining the difference between the two communities.

\section{RESULTS AND DISCUSSION}

\subsection{Population aging in Vietnam and the rural} area of Thua Thien Hue Province

4.1.1 Population aging in Vietnam

Over the past three decades, the Vietnamese population has changed significantly in terms of size and age structure. As a result of sharp reductions in fertility and mortality as well as increased life expectancy at birth, the elderly population in Vietnam is increasing rapidly in both absolute and relative numbers. According to the United Nations Economic and Social Commission for Asia and the Pacific, a population begins aging when the percentage 
of elderly persons to the total population represents more than 10 percent [9]. Table 2 illustrates that the Vietnamese population entered into the so-called "aging phase" from 2014 onward.

Table 2

Chronologic Vietnamese population and Population structure by age group

\begin{tabular}{|l|l|l|l|l|l|l|l|}
\hline \multirow{2}{*}{ Year } & \multirow{2}{*}{$\begin{array}{l}\text { Total population } \\
\text { (Thousand persons) }\end{array}$} & $\begin{array}{l}\text { Population aged } 60 \\
\text { and over } \\
\text { (Million persons) }\end{array}$ & \multirow{2}{*}{$\begin{array}{l}\text { Life expectancy } \\
\text { at birth } \\
\text { (Years old) }\end{array}$} & \multicolumn{5}{|l|}{ Population structure by age group (\%) } \\
\cline { 5 - 9 } & & & $0-14$ & $15-59$ & $60+$ & $65+$ \\
\hline 1999 & 76,323 & 6.11 & 72.8 & 33.1 & 58.9 & 8.0 & 5.8 \\
\hline 2009 & 85,847 & 7.73 & 73.2 & 25.0 & 66.0 & 9.0 & 6.4 \\
\hline 2014 & 90,493 & 9.23 & 23.5 & 66.3 & 10.2 & 7.1 \\
\hline
\end{tabular}

Life expectancy at birth was 73.2 in 2014, an increase of 0.4 years and 5 years in comparison with 2009 and 1999, respectively. In addition, the rural-urban migration trend is more and more popular. During the period of 1999-2009, there was a strong increase of the migration population proportion in the ruralurban flow from $27.1 \%$ to $31.4 \%$ of the total population over five years of age with the migrants in the five years prior to the survey. In 2014 , the rural-urban migration population accounted for $29 \%$ of the total migration population. However, this flow still accounts for a relatively high proportion of all migrants in comparison with other migration flows (rural-rural, urban-rural, and urban-urban).
Given the aforementioned evidence, Vietnam is revealed to be in the beginning period of the "aging phase" with the popular migration from the rural areas to the urban areas, or out of their homeland for the purpose of obtaining jobs and promoting their family income. Therefore, the process of Kaso in Japan can also occur in Vietnam and will negatively impact the development of the community in rural areas.

4.1.2 Population aging in Thua Thien Hue Province

Thua Thien Hue's population structure by age group is presented in Table 3 .

Table 3

Thua Thien Hue population structure by age group

\begin{tabular}{|l|l|l|l|l|l|}
\hline \multirow{2}{*}{ Year } & \multirow{2}{*}{$\begin{array}{l}\text { Total population } \\
\text { (persons) }\end{array}$} & Population aged 60 and over & \multicolumn{2}{|l|}{ Population structure by age group (\%) } \\
\cline { 4 - 6 } & & & $0-14$ & $15-59$ & $60+$ \\
\hline 1999 & $1,044,875$ & 97,974 & 36.0 & 54.7 & 9.4 \\
\hline 2009 & $1,088,822$ & 112,377 & 27.5 & 62.1 & 10.3 \\
\hline 2012 & $1,115,523$ & 120,479 & 25.3 & 63.9 & 10.8 \\
\hline 2014 & $1,135,568$ & 135,207 & 24.0 & 63.9 & 12.1 \\
\hline
\end{tabular}

Table 3 reveals that the proportion of people aged 60 and over is increasing, and Thua Thien Hue is facing an aging population. In addition, this is one of the four provinces with the highest proportion of rural-urban flow in comparison with other provinces in the whole country. The rural area of Thua Thien Hue Province consists of 104 communes belonging to two towns (Huong Thuy and Huong Tra) and six rural districts (A Luoi, Nam Dong, Phu Loc, Phu Vang, Phong Dien, and Quang Dien). The rural population proportion accounts for $34 \%$ of the total population. According to the authors' survey results, the main migration areas of Thua Thien Hue rural communes are the great cities, especially Ho Chi Minh City and Hanoi. 


\subsection{Categorization of the rural aging population communes}

Based on the data of the total population and the population structure of rural communes collected from the Thua Thien Hue Statistics Office in
1989 , especially that of the period of 1992-2012, a typology analysis was implemented by communelevel administrative units. The analysis results significant for study are presented in detail in Table 4.

Table 4

Typology analysis results of population in Thua Thien Hue by rural commune

\begin{tabular}{|c|c|c|c|c|}
\hline \multirow[b]{2}{*}{ No } & \multirow[b]{2}{*}{ District/town } & \multicolumn{2}{|c|}{ Population characteristics by commune $1989-2012$} & \multirow{2}{*}{$\begin{array}{l}\text { Total population and } \\
\text { young population } \\
\text { decrease }\end{array}$} \\
\hline & & $\begin{array}{l}\text { Total population decrease, } \\
\text { over } 30 \% \text { of the total }\end{array}$ & $\begin{array}{l}\text { Decrease of people under } 15 \text { years, } \\
\text { under } 30 \% \text { of the total }\end{array}$ & \\
\hline 1 & Phu Vang & Phu Thuan, Vinh Xuan & $\begin{array}{l}\text { Phu Thuan, Vinh Xuan, Phu Thanh, } \\
\text { Vinh Phu }\end{array}$ & $\begin{array}{l}\text { Phu Thuan, Vinh } \\
\text { Xuan }\end{array}$ \\
\hline 2 & Phong Dien & Phong Thu, Dien Mon & $\begin{array}{l}\text { Phong Thu, Dien Mon, Phong } \\
\text { Chuong, Phong Hoa, Dien Hai, } \\
\text { Phong Thu, Phong Son }\end{array}$ & Phong Thu, Dien Mon \\
\hline 3 & Quang Dien & Quang Phuoc & Quang An, Quang Phuoc & Quang Phuoc \\
\hline 4 & Phu Loc & & Vinh Hai, Loc Hoa, Vinh My & \\
\hline 5 & Nam Dong & Huong Loc & Huong Loc & Huong Loc \\
\hline 6 & A Luoi & Son Thuy & Son Thuy, Phu Vinh, Dong Son & Son Thuy \\
\hline 7 & Huong Thuy & Duong Hoa & Duong Hoa, Phu Son & Duong Hoa \\
\hline 8 & Huong Tra & & Hai Duong & \\
\hline
\end{tabular}

With the purpose of recognizing the local people's consciousness on community development, the two communes chosen for interviews administered to local households by questionnaire were Quang Phuoc (Quang Dien
District) and Huong Loc (Nam Dong District), which represent two plain and mountainous areas. Quang Phuoc and Huong Loc both have an elderly population aged 60 and above in Thua Thien Hue Province that is increasing [8]

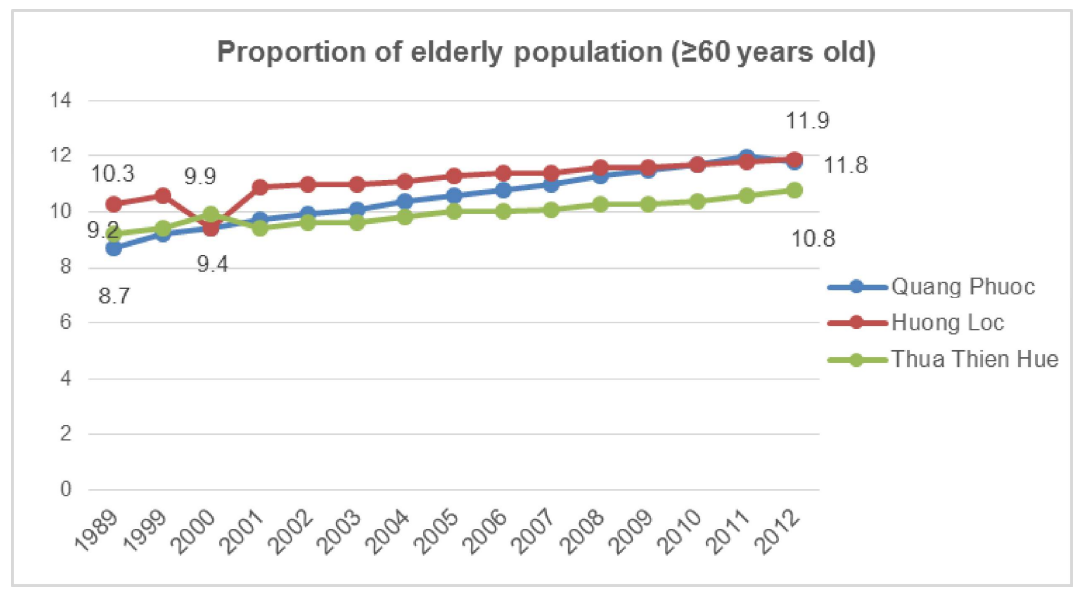

Figure 2. Proportion of elderly population aged 60 and above by year (\%)

These communes have a proportion of elderly population aged 60 and over that is higher than the average proportion of Thua Thien Hue Province. The total number of people living outside their homeland are rather high and account for $20-30 \%$ of the people who are of working age. The secondary school dropouts are increasing because they want to go far to obtain jobs and improve their economic conditions. These will affect the local area both negatively and positively in regards to socio-economic issues. For the implementation of the field survey, a total of two rural communities were selected representing two characteristic areas. From Quang Phuoc, a mountainous commune, one community was selected, namely Thon 3 Village, and the second selected area, Thu Le 3 Village, is characterized by plains. These two communities were selected for the field survey based on interviewing the Commune People's Committee leaders and the conditions, as follows: (i) full basic data; (ii) suitable for the research content of 
population aging, local characteristics, and presentation for geographic areas (plain and mountainous); (iii) the village head is enthusiastic and knowledgeable about the local area and people (Fig. 3).

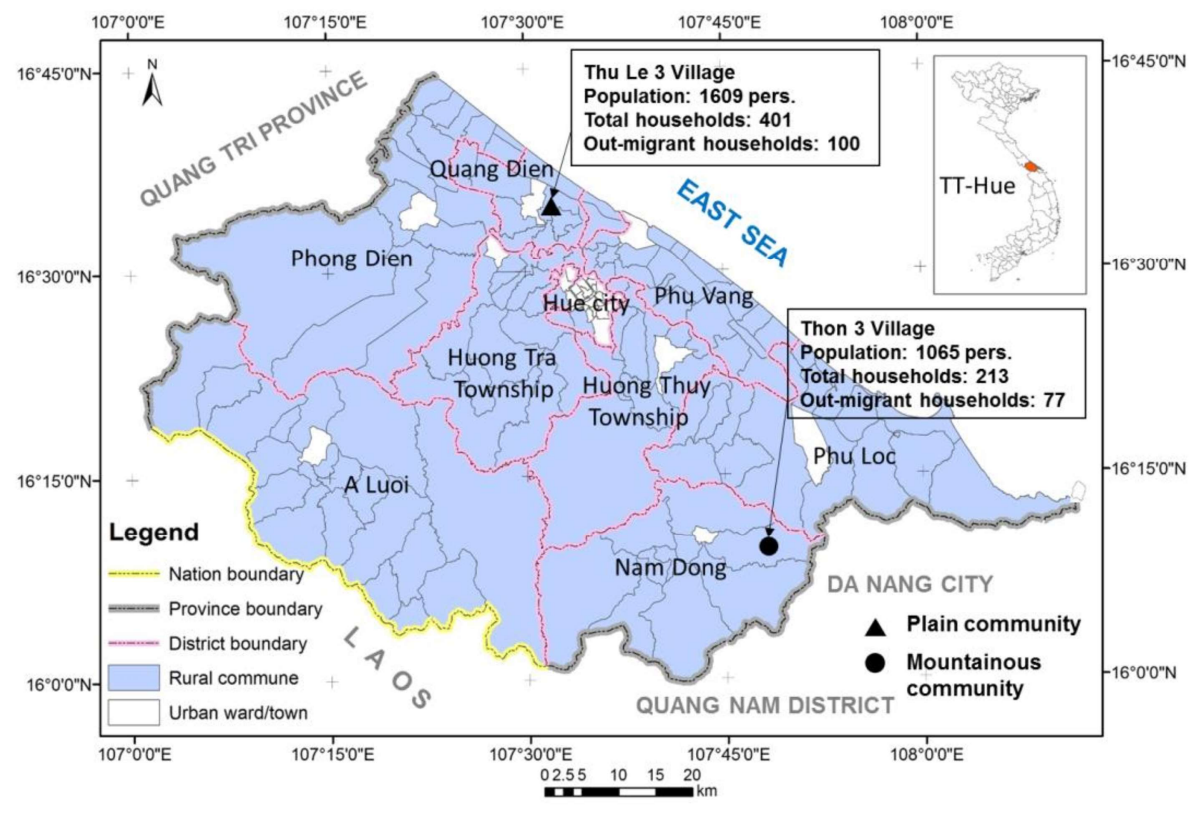

Figure 3. Map of study area with two target rural communities

\subsection{Characteristics of surveyed communes}

The selected sample size is 85 households in the Thu Le 3 Village (Quang Phuoc Commune, Quang Dien District) and the Thon 3 Village
(Huong Loc Commune, Nam Dong District). Some information on the selected villages to interview in 2014 is presented in Table 5.

Table 5

Characteristics of selected villages for conveying questionnaire survey

\begin{tabular}{|c|c|c|c|c|c|c|}
\hline No & Village name & $\begin{array}{l}\text { Total } \\
\text { households }\end{array}$ & $\begin{array}{l}\text { Total } \\
\text { population }\end{array}$ & $\begin{array}{l}\text { Population in } \\
\text { working age }\end{array}$ & $\begin{array}{l}\text { Households } \\
\text { with out- } \\
\text { migrants } \\
\end{array}$ & $\begin{array}{l}\text { Migration places to } \\
\text { obtain jobs }\end{array}$ \\
\hline 1 & Thu Le 3 & 401 & 1609 & 1009 & 100 & $\begin{array}{l}\text { Ho Chi Minh City, } \\
\text { Hue City, Laos... }\end{array}$ \\
\hline 2 & Thon 3 & 213 & 1065 & 540 & 77 & $\begin{array}{l}\text { Đaklak, Da Nang, } \\
\text { Ho Chi Minh } \\
\text { City... }\end{array}$ \\
\hline . & Total & 614 & 6144 & 1540 & 177 & \\
\hline
\end{tabular}

Table 6

Number of interviewed households by village

\begin{tabular}{|l|l|l|}
\hline Survey area & Total households & Sample size $(\mathbf{E}= \pm \mathbf{1 0} \%)$ \\
\hline Thu Le 3 & 401 & 56 \\
\hline Thon 3 & 213 & 29 \\
\hline Total & 6144 & 85 \\
\hline
\end{tabular}


Results from the overall sample of the household survey indicated that the sample is not particularly unequal in terms of gender, comprising $76.47 \%$ male and $23.53 \%$ female respondents. On average, $85.88 \%$ of the sample respondents were working in the agricultureforestry-aquaculture sector. In terms of desirableness to return to the hometown of family members working outside (in big cities or urban areas), more than $65 \%$ of all respondents were given, ranging from $59.10 \%$ in Thon 3 Village to $72.73 \%$ in Thu Le 3 Village. In contrast, the agreement percentage of respondents in terms of "Successors on agriculture-forestry-aquaculture development in the future" accounted for a mere average of $20.55 \%$, comprising $16.33 \%$ and $29.17 \%$ for Thu Le 3 Village and Thon 3 Village, respectively.

The preliminary analysis result shows that while agriculture-forestry-aquaculture sector is the main branch of the local economy, the proportion of successors is low. This can be associated with the risk of economic decline in the rural areas and negative effect on the community development.

\subsection{Consciousness of rural residents on community development}

In order to illustrate the difference in consciousness on community development of residents, a comparative analysis was conducted on the following dimensions: living conditions of community, natural-socio-economic characteristics of community, present community development concerns, and future community concerns. The overall scores of rural residents' consciousness on community development was mapped by calculating each dimension as depicted in Figure 4, in which the scores of Thu Le 3 Village are located on the solid line and those of Thon 3 Village are depicted on the dash line, with the average of 2.86 and 2.79, respectively. The shape of the radar diagram clearly shows that the level of inhabitants' consciousness on community development in Thu Le 3 village is slightly higher than that in Thon 3 Village, especially in terms of future community development concern.

\section{Conciousness of rural residents on community development}

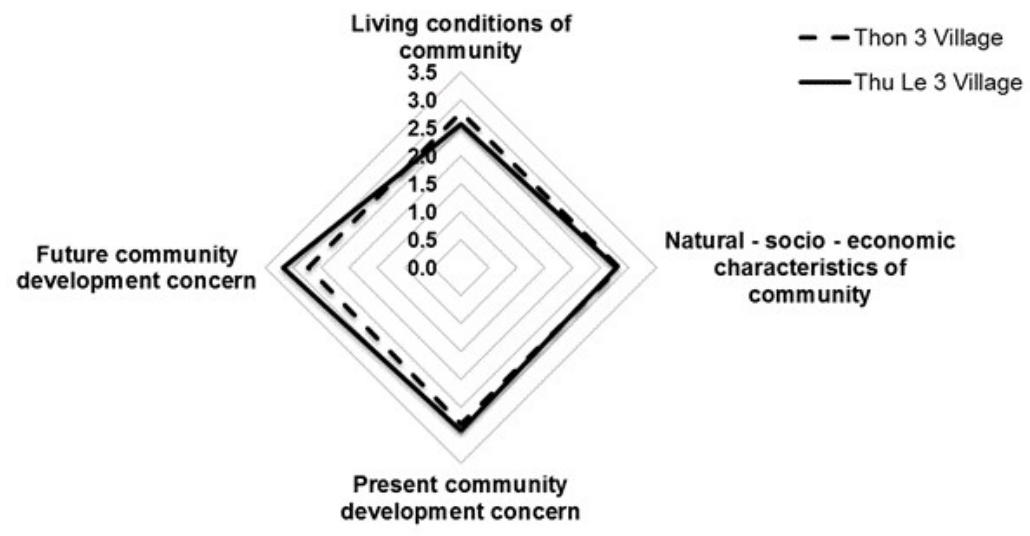

Figure 4. Consciousness of rural residents on community development

A detailed radar diagram of each dimension of residents' consciousness is presented in Figure 5. The living conditions of community point out the considerable difference in range of scores between the variables. For instance, public health service and education appeared to differ among the two villages, where Thon 3 (the mountainous area) had a higher score than Thu Le 3 (the plain area) by nearly three points. This may be associated with the fact that the residents in Thon 3 feel satisfied with their current living conditions, although in reality the systems of education and health service scarcely meet public demands.

The natural and socio-economic characteristics of the community dimension showed a significant variation in natural landscape, employment opportunity, and local economic change between the two villages. Thon 3 Village highlighted a high score in employment opportunity and abundant natural landscape, while revealing a low score in trend of local economic change. This strength in Thon 3 Village may be due to its 
original village and the high forestry resources for exploitation of the inherent territory. Meanwhile, in the village of Thu Le 3, although it showed a high rate of household economy change and local economy change over the last 10 years (more than 3.2 ), the employment opportunity just merely reached a low score (with an average of 2.3).
Living conditions of community

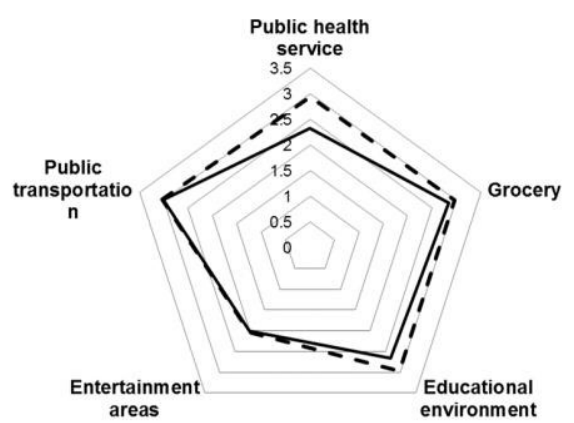

Natural - socio - economic
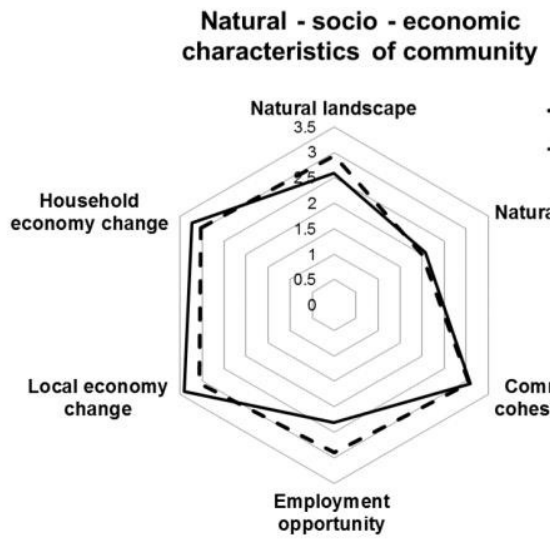

Present community

development concerns

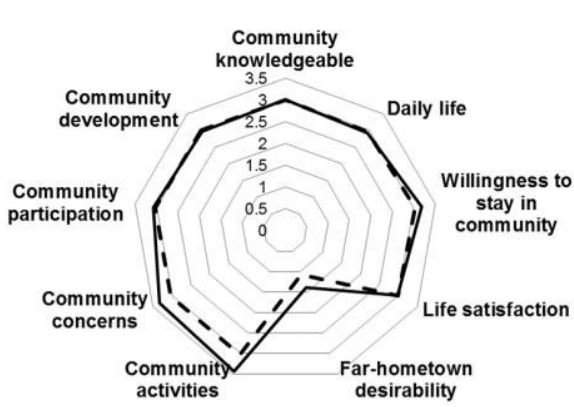

Figure 5. Four dimensions of characteristics of rural resident's consciousness on community development

The present community development concerns dimension indicated a similar trend among both the villages. In particular, the concerns of local people in migration are very low, ranging from 1.06 to 1.38 in Thon 3 and Thu Le 3 Village, respectively. Almost all the respondents expressed that they do not want to live far from their hometown or their family. Respondents consistently expressed a warm and sincere emotion in regards to their community life and enjoy participating in community-based activities contributing to strengthen their community. Therefore, almost all the variables revealed a high score (with an average from 2.93 to 3.43).

Based on the positive awareness of the local people on living conditions, natural-socioeconomic characteristics, and present community development concerns, the results of future community development concerns showed a high score among both villages in community life and new community activity expectation (above 3.0 ).
However, in terms of out-migration trends among the young generation, a relatively high score was indicated, ranging from 2.14 to 3.0 in Thon 3 and Thu Le 3 Village, respectively. This can be explained by the fact that the rural residents still desire to achieve a high income and new opportunities in big cities (Hanoi, Ho Chi Minh, or even Lao People's Democratic Republic) for a certain period and will come back to their homeland. In particular, Thu Le 3 Village depicted a high score of out-migration desirableness (3 points) when the occupation opportunities showed a decreasing trend over recent years.

\section{CONCLUSION AND RECOMMENDATION}

From the research results, some conclusions and recommendations may be offered, as follows:

Since 1986, the Vietnamese government initiated the Doi Moi policy and is making the 
transition to a market economy. It follows, therefore, that Vietnam achieved a high economic growth and industrialization in and around $\mathrm{Ho} \mathrm{Chi}$ Minh City and Hanoi from the latter half of the 1990 s to the 2000s. This industrialization in Vietnamese urban areas was supported by outflows of a younger labor force from rural areas. Consequentially, since the beginning of the 2010s, there has been a gradual increase in rural people's concern over the aging population in their communities. Given the aforementioned evidence, it can be revealed that Vietnam is in the beginning period of the "aging phase". Some occurred intinial signs of the process of Kaso were identified as the popular migration from the rural areas to the urban areas, or out of their homeland for the purpose of obtaining jobs and promoting their family income. It is thus necessary to conduct more thorough researches on this process.

- From the results of the present analyses, the presence of rural people's negative consciousness of community development is not strong. However, residents of Thon 3 Village have displayed a powerful interest in urban life. Based upon the results of this research, we can consider that the urban orientation of rural people in Vietnam arise not from a push factor of rural areas, but from a pull factor of urban areas.

- This is similar to the initial situation of Kaso in rural Japan. We consider that the "process of spiral on Kaso" may offer applicability to clarify the present and future state of the rural community as a source of an urban labor force. In particular, we emphasize significant importance on providing implicit information on the negative consciousness of rural people regarding the future of rural Vietnam.

\section{ACKNOWLEDGEMENT}

This paper is a portion of the findings revealed in "The Research Project on Problems of Kaso-Ka in Rural Areas in Middle-Vietnam" (project leader: TSUTSUI Kazunobu) supported by the HEIWA-NAKAJIMA Foundation, Japan.

\section{REFERENCES}

[1]. ADACHI Ikutsune. "KASO no Jittai - the real condition of Kaso," Jurist, No.455, pp.21-25 (1970)

[2]. General Statistics Office of Vietnam - GSO. The 2014 Intercensal Population and Housing Survey: Some key indicators, Hanoi (2015)

[3]. General Statistics Office of Vietnam - GSO. The 2014 Intercensal Population and Housing Survey: Migration and urbanization in Vietnam, Vietnam News Agency Publishing House, Hanoi (2016).

[4]. Gary Paul Green and A. Goetting. Mobilizing Communities - Asset Building as a Community Development Strategy. Temple University Press, 1601 North Broad Street, Philadelphia PA 19122 (2010).

[5]. Do Thi Viet Huong, Kazunobu Tsutsui, Ryota Nagasawa. Assessing Community Resilience to Flood disasters in Rural District of Da Nang City, Vietnam, Journal of Rural Planning, Vol.33, No.1, pp.64-73, Japan (2014).

[6]. Ni Made Sofia Wijaya. Contemporary Problems in Japan's Rural Areas and Opportunities for Developing Rural Tourism: A Case of Yamashiro District in Yamaguchi Prefecture, Journal of East Asian Studies, No. 11, 2013.3., pp. 59-72, Japan (2013)

[7]. Thinh Nguyen Viet, Duc Do Thi Minh. Textbook on Socio-economic Geography of Vietnam, Education Publisher, Hanoi, Vietnam (2001).

[8]. Thua Thien Hue Statistical Office. Statistical data on elderly population aged 60 and above by commune in Thua Thien Hue Province (in 1989, 1999-2012). Statistical dataset was ordered particularly for HEIWANAKAJIMA project, Hue (2014).

[9]. United Nations Population Fund (UNFPA) in Vietnam. The Aging Population in Vietnam - Current status, prognosis, and possible policy responses, Hanoi (2011)

[10]. United Nations, Department of Economic and Social Affairs, Population Division. World Population Ageing 2015 (ST/ESA/SER.A/390), (2015).

[11]. Yamane Taro. Elementary Sampling Theory, PrenticeHall, Inc., Englewood, N. J (1967) 


\title{
Già hóa dân số và nhận thức của người dân về phát triển cộng đồng: Trường hợp nghiên cứu ở khu vực nông thôn tỉnh Thừa Thiên Huế, Việt Nam
}

\author{
Bùi Thị Thu', *, Tsutsui Kazunobu², Đỗ Thị Việt Hương ${ }^{1}$ \\ ${ }^{1}$ Trường Đại học Khoa học, Đại học Huế \\ ${ }^{2}$ Đại học Tottori \\ Email tác giả liên hệ: lapthuhue@gmail.com
}

Ngày nhận bản thảo: 10-10-2017; Ngày chấp nhận đăng: 18-11-2017; Ngày đăng: 30-6-2018

Tóm tắt-Già hoá dân số là một hiện tượng toàn cầu đã tác động mạnh mẽ đến đời sống xã hội ở trên thế giới. Trong đó, Nhật Bản và Việt Nam là 2 trong số 20 quốc gia có số người già lớn nhất thế giới. Hiện tượng "Kaso" - "Suy giảm dân số" đã xảy ra ở vùng nông thôn Nhật Bản vào thập niên 60 của thế kỷ 20 và đã tác động tiêu cực đến sự phát triển cộng đồng. Việt Nam nói chung và tỉnh Thừa Thiên Huế nói riêng đang bắt đầu quá trình già hóa dân số - một trong những dấu hiệu của Kaso. Bài báo này nhằm làm sáng tỏ (1) mức độ "Kaso" ở Nhật Bản xảy ra ở khu vục nghiên cứu của Việt Nam như thế nào; và (2) nhận thức của người dân về cuộc sống hằng ngày, tình hình phát triển kinh tế - xã hội và sự quan tâm của người dân địa phương như thế nào về sự phát triển của cộng đồng trong bối cảnh dự báo già hóa dân số. Dựa trên kết quả phân kiểu sơ bộ số liệu thống kê nhân khẩu (tổng dân số, cấu trúc dân số theo độ tuổi) của Thừa Thiên Huế theo đơn vị hành chính cấp xã giai đoạn 1989 - 2012, hai xã nông thôn với các đặc trưng già hóa dân số đã được lựa chọn để nghiên cứu chuyên sâu thông qua điều tra phỏng vấn hộ gia đình. Kết quả nghiên cứu cho thấy, đã có những dấu hiệu ban đầu của hiện tượng Kaso như ở Nhật Bản. Tuy nhiên, kết quả phân tích sâu thì chưa thấy rõ nhận thức tiêu cực của người dân nông thôn về phát triển cộng đồng. Kết quả này góp phần nhấn mạnh tầm quan trọng của việc tiếp tục nghiên cứu nhận thức của người dân về phát triển cộng đồng nông thôn Việt Nam trong tương lai.

Từ khóa-Già hóa dân số, Kaso, phát triển cộng đồng, khu vực nông thôn, tỉnh Thừa Thiên Huế 